\section{Variation in Soil pH and Calcium Status Influenced by Microsprinkler Wetting Pattern for Young Citrus Trees}

\author{
AK. Alva \\ University of Florida, Institute of Food and Agricultural Sciences, Citrus \\ Research and Education Center, 700 Experiment Station Road, Luke Alfred, \\ FL 33850
}

T.A.Obreza ${ }^{1}$

University of Florida, Institute of Food and Agricultural Sciences, Southwest Florida Research and Education Center, P. O. Drawer 5127, Immokalee, FL 33934

Additional index words. bicarbonate, calcium, flatwoods soils, low-volume irrigation, water quality

\begin{abstract}
Deep aquifer water, which contains high levels of bicarbonate and $\mathrm{Ca}$, is used predominantly for citrus irrigation. Changes in soil $\mathbf{~ p H}$ and Mehlich 1 extractable Ca concentrations were examined inside and outside the microsprinkler-wetted zone in 3- to 5 -year-old citrus groves on three soils. Soil $\mathrm{pH}$ at 0 to $15 \mathrm{~cm}$ inside the wetted zone was 0.4 , 0.9 , and $1.3 \mathrm{pH}$ units higher than that outside the wetted zone in Immokalee, Myakka, and Holopaw sands, respectively. This pH increase was due to the addition of bicarbonate in the irrigation water. Extractable Ca concentrations were also about two-fold higher inside compared to those outside the wetted zone at depths of $O$ to 15 and 15 to $30 \mathrm{~cm}$. With young trees, a majority of the roots are within the microsprinkler-wetted zone; therefore, soil samples should be taken inside the wetted zone for measuring soil $\mathrm{pH}$ and status of plant nutrients.
\end{abstract}

Irrigation water quality affects soil properties and soil productivity. Groundwater from limestone aquifers, common in many parts of Florida, contains a high amount of dissolved bicarbonates. Calcium carbonate precipitation is associated with well-water use in irrigated rice (Oryza sativa L.) in the Grand Prairie area of Arkansas (Ferguson and Gilmour, 1981; Ferguson et al., 1975; Gilmour and Ferguson, 198 1; Gilmour et al., 1978; Marx et al., 1988).

Soil $\mathrm{pH}$ under a drip irrigation system (bicarbonate concentration in the water $=2.1$ $\mathrm{meq} / \mathrm{liter}$ ) increased from 5.0 (native soil $\mathrm{pH}$ ) to 7.6 [L.A. Halsey, unpublished data; cited by Kidder and Hanlon (1985)]. Soil pH was 5.5 outside wetting zone of the dripper.

Soil $\mathrm{pH}$ affects plant nutrient availability, plant growth, and production. The availability of most micronutrients in soils is reduced at $\mathrm{pH}>7.0$ (Mortvedt et al., 1972). Maintaining the soil pH between 6.0 to 7.0 is recommended for Florida citrus production (Koo et al., 1984), based on studies conducted on deep, sandy, nonirrigated ridge soils in central Florida

Received for publication 7 Jan. 1993. Accepted for publication 12 July 1993. Florida Agricultural Experiment Station journal series no. R-02906. Research was conducted at the Citrus Research and Education Center, Lake Alfred, Fla. The cost of publishing this paper was defrayed in part by the paymentof page charges. Under postal regulations, this paper therefore must be hereby marked advertisement solely to indicate this fact.

'Assistant Professor.
(Anderson, 1971; Anderson and Calvert, 1965). Since the early 1980s, low-volume or microirrigation has become increasingly popular in Florida citrus production (Parsons, 1989). This irrigation system is designed to apply water to a restricted area around the trees.

Citrus planting has recently expanded in the southern part of the state. Most of the new plantings are irrigated with low-volume microsprinklers. Soils in this region, referred to as "flatwoods" soils, are shallow and poorly drained. Groundwater is the dominant source for citrus irrigation. The deep well water contains high levels of bicarbonate and $\mathrm{Ca}$ because of the limestone substratum.

Data from the ambient groundwater quality monitoring program administered by the Southwest Florida Water Management District showed that water in nearly $90 \%$ of 540 wells tested had a pH >7.0; $\approx 80 \%$ of the wells had bicarbonate concentration $>100 \mathrm{mg} \cdot$ liter $^{-1}$ (Jones et al., 1990).

The majority of soils in Florida citrusproducing areas are sandy and low in organic matter (Carlislie et al., 1989). These soils also are low in buffering capacity; therefore, their $\mathrm{pH}$ may fluctuate with the continuous addition of bicarbonate through irrigation water. Since microsprinkler irrigation applies water over only a small portion of the entire grove area, the impact of irrigation water on localized soil properties is expected to be much greater than that from overhead irrigation.

The objective of this study was to evaluate the effects of microsprinkler irrigation on soil $\mathrm{pH}$ and $\mathrm{Ca}$ content inside the microsprinkler wetting zone in newly planted groves representing varying soil types, tree age, scheduling, and total irrigation duration.

Three commercial citrus groves near Immokalee, in Hendry County, Fla., were sampled for this study. Before planting, the soils in all three sites were undisturbed and contained native vegetation. Since these soils are poorly drained in their native state, a doublerow, raised-bed planting method was employed. During bedding, the soil from the water furrow was deposited over the original topsoil along the bed where the trees were planted. Soil characteristics and grove descriptions used for soil sampling are shown in Table 1.

Soil samples were taken at 0 - to $15-\mathrm{cm}$ and 15- to $30-\mathrm{cm}$ depths within $30 \mathrm{~cm}$ from the emitters and also outside the emitter wetting zone. The sampling unit for this study at each of the three locations was $\approx 0.4$ ha. Within each sampling unit, five replicate samples were taken from alternate rows. Within a row chosen for sampling, 20 cores $(2.5 \mathrm{~cm}$ in diameter) of soil were collected and pooled to represent one sample for each sampling depth and sampling position.

The composite soil samples were mixed thoroughly, air-dried, and screened to pass a 2$\mathrm{mm}$ sieve. Soil $\mathrm{pH}$ was measured in a 1 soil: 1 water (weight/volume) suspension. For Mehlich 1 (Ml; Mehlich, 1953) extraction, 20 $\mathrm{ml}$ of the extractant $(0.048 \mathrm{M} \mathrm{HC} 1+0.0104 \mathrm{M}$ $\mathrm{H}_{2} \mathrm{SO}_{4}$ ) was added to $5 \mathrm{~g}$ soil, shaken for 5 rein, and filtered through Whatman no. 40 filter paper. The $\mathrm{Ca}$ concentration in the filtrate was measured by inductively coupled plasma emission spectroscopy (model Plasma 40; Pet-kin-Elmer Corp., Norwalk, Corm.). The three soils were treated independently for statistical analysis. The significance of sampling position (i.e., inside vs. outside the wetted zone) on the soil $\mathrm{pH}$ and M1-Ca concentration was evaluated using a t test at two sampling depths.

At each of the three sites, the irrigation well water was analyzed for $\mathrm{Ca}$ and bicarbonate concentrations. The water sample was collected after the pump ran for $\gg 1 \mathrm{~h}$. Three subsamples of $\approx 500 \mathrm{ml}$ were collected at each site. These samples were analyzed separately and the mean values are given for each site (Table 1). The composition of ground water with respect to $\mathrm{Ca}$ and bicarbonate concentrations will not vary rapidly; thus, results of one sampling are adequate to demonstrate the properties of the irrigation water.

Soil sampling location in reference to the microsprinkler-wetted zone had a significant effect on soil $\mathrm{pH}$ and $\mathrm{Ca}$ concentration (Table 2). Soil $\mathrm{pH}$ at the 0 -to $15-\mathrm{cm}$ depth was greater by $1.3,0.4$, and $0.9 \mathrm{pH}$ units inside the wetted zone, as compared to those outside the wetted zone, in the Holopaw, Immokalee, and Myakka sands, respectively; the corresponding $\mathrm{pH}$ increases at the 15-to 30-cm depth were 2.0,0.6, and 2.2. In most soils, the $\mathrm{pH}$ is higher in the surface horizon than at deeper horizons. This trend was clearly shown in samples taken outside the microsprinkler-wetted zone at all three sites (Table 2). However, on samples 
Table 1. Soil types and details of irrigation practices employed in citrus groves sampled in this study.

\begin{tabular}{|c|c|c|c|c|c|c|c|c|c|}
\hline \multirow{2}{*}{$\begin{array}{l}\text { Site } \\
\text { no. }\end{array}$} & \multirow{2}{*}{$\begin{array}{c}\text { Soil } \\
\text { series }\end{array}$} & \multirow{2}{*}{$\begin{array}{l}\text { Taxonomic } \\
\text { classification }\end{array}$} & \multirow{2}{*}{$\begin{array}{l}\text { Tree } \\
\text { age } \\
(\mathrm{yr}) \\
\end{array}$} & \multirow[b]{2}{*}{ Scion/rootstock } & \multirow[b]{2}{*}{ Emitter } & \multirow{2}{*}{$\begin{array}{c}\text { Rate of } \\
\text { discharge } \\
\left(\mathrm{m}^{3} \cdot \mathrm{h}^{-1}\right)\end{array}$} & \multirow{2}{*}{$\begin{array}{c}\text { Approx. } \\
\text { irrigation } \\
\text { scheduling }\end{array}$} & \multicolumn{2}{|c|}{$\begin{array}{c}\text { Concn in irrigation } \\
\text { water (meq/liter) }\end{array}$} \\
\hline & & & & & & & & $\mathrm{Ca}$ & Bicarbonate \\
\hline 1 & $\begin{array}{l}\text { Holopaw } \\
\text { sand }\end{array}$ & $\begin{array}{l}\text { Loamy, siliceous, } \\
\text { hyperthermic, } \\
\text { Grossarenic } \\
\text { Ochraqualfs }\end{array}$ & 3 & $\begin{array}{l}\text { Hamlin }^{2} \text { on Carrizo } \\
\text { citrange or Swingle } \\
\text { citrumelo }\end{array}$ & $\begin{array}{l}\text { Dan pressure } \\
\text { compensation }\end{array}$ & 0.038 & $\begin{array}{l}1 \text { h every } \\
3 \text { days }\end{array}$ & 4.6 & 6.0 \\
\hline 2. & $\begin{array}{l}\text { Immokalee } \\
\text { fine sand }\end{array}$ & $\begin{array}{l}\text { Sandy, siliceous, } \\
\text { hyperthermic, Arenic } \\
\text { Haplaquods }\end{array}$ & 3 & $\begin{array}{l}\text { Budwood grove; } \\
\text { several scions } \\
\text { and rootstocks }\end{array}$ & Rainbird & 0.087 & $6-7 \mathrm{~h} / \mathrm{wk}$ & 3.8 & 4.7 \\
\hline 3 & $\begin{array}{l}\text { Myakka } \\
\text { sand }\end{array}$ & $\begin{array}{l}\text { Sandy, siliceous, } \\
\text { hyperthermic, Arenic } \\
\text { Haplaquods }\end{array}$ & 5 & $\begin{array}{l}\text { Red grapefruit }{ }^{y} \text { on } \\
\text { Swingle citrumelo }\end{array}$ & Danjet & 0.038 & $\begin{array}{l}1.5 \mathrm{~h} / \\
\text { application, } \\
6 \text { times/wk }\end{array}$ & 1.4 & 3.8 \\
\hline
\end{tabular}

z'Hamlin' orange [Citrus sinensis (L.) Osb.].

y'Ruby Red' grapefruit (Citrus paradisi MacFad.)

taken inside the wetted zone, sampling depth had little effect on $\mathrm{pH}$. These results suggest that the role of irrigation water in raising soil $\mathrm{pH}$ was not restricted to $15 \mathrm{~cm}$ of topsoil. In these sandy soils, $\mathrm{Ca}$ and bicarbonate in the irrigation water may have been leached below the $15 \mathrm{~cm}$ of topsoil to cause changes in $\mathrm{pH}$.

An increase in soil $\mathrm{pH}$ inside the microsprinkler-wetted zone also was associated with an increase in $\mathrm{Ca}$ content (Table 2). Soil $\mathrm{Ca}$ concentration at the $0-$ to $15-\mathrm{cm}$ depth inside the wetted zone exceeded that outside by $82 \%$, $19 \%$, and $74 \%$ for Holopaw, Immokalee, and Myakka sand, respectively; the corresponding values at 15 to $30 \mathrm{~cm}$ were $72 \%, 63 \%$, and $401 \%$. With the exception of Holopaw sand, the $\mathrm{Ca}$ concentrations outside the wetted zone were much lower at 15 to $30 \mathrm{~cm}$ than at 0 to 15 $\mathrm{cm}$. However, for soil samples taken inside the wetted zone, Ca concentration at 15 to $30 \mathrm{~cm}$ was either slightly lower or higher than that at 0 to $15 \mathrm{~cm}$. Therefore, the buildup of $\mathrm{Ca}$ in soils as a result of high $\mathrm{Ca}$ in the irrigation water was evident at both sampling depths.

In summary, this study demonstrated an increase in soil $\mathrm{pH}$ and $\mathrm{Ca}$ concentration within the microsprinkler-wetted zone. The bulk of the root system of young citrus trees is within the microsprinkler-wetted zone. Therefore, the soil $\mathrm{pH}$ and nutrient availability within this zone is important for tree growth. The position of routine soil sampling with respect to the microsprinkler-wetted zone is important for $\mathrm{pH}$ determination. If soil samples are taken outside the wetted zone, the measured $\mathrm{pH}$ could underestimate the actual $\mathrm{pH}$ within the wetted zone. In such a situation, lime applications based on measured $\mathrm{pH}$ outside the wetted zone may raise the $\mathrm{pH}$ within the wetted zone or primary root zone beyond the desired range. It is also important to analyze irrigation water for $\mathrm{pH}, \mathrm{Ca}$, and bicarbonate contents.

Table 2. Soil pH and Mehlich 1 (Ml) extractable Ca status in three soils as influenced by position of sampling in relation to microjet wetting pattern.

\begin{tabular}{|c|c|c|c|c|c|}
\hline \multirow[b]{2}{*}{ Soil series } & \multirow{2}{*}{$\begin{array}{c}\text { In/out of } \\
\text { wetting } \\
\text { zone }\end{array}$} & \multicolumn{2}{|c|}{$\frac{\mathrm{pH}}{\text { Depth }(\mathrm{cm})}$} & \multicolumn{2}{|c|}{$\frac{\mathrm{Ml}-\mathrm{Ca}\left(\mathrm{mg} \cdot \mathrm{kg}^{-1}\right)}{\text { Depth }(\mathrm{cm})}$} \\
\hline & & $0-15$ & $15-30$ & $0-15$ & $15-30$ \\
\hline \multirow[t]{2}{*}{ Holopaw sand } & In & 7.4 & 7.1 & 988 & 1212 \\
\hline & Out & 6.1 & 5.1 . & 542 & 704 \\
\hline Prob $>\mathbf{T}$ & & $<0.001$ & $<0.001$ & $<0.001$ & $<0.001$ \\
\hline \multirow[t]{2}{*}{ Immokalee fine sand } & In & 6.0 & 5.9 & 926 & 879 \\
\hline & Out & 5.6 & 5.3 & 775 & 538 \\
\hline Prob $>\mathrm{T}$ & & 0.018 & 0.009 & 0.020 & $<0.001$ \\
\hline \multirow[t]{2}{*}{ Myakka sand } & In & 6.3 & 6.5 & 601 & 732 \\
\hline & Out & 5.4 & 4.3 & 345 & 146 \\
\hline Prob $>T$ & & 0.024 & $<0.001$ & 0.020 & $<0.001$ \\
\hline
\end{tabular}

\section{Literature Cited}

Anderson,C.A.1971.Effectsof soil $\mathrm{pH}$ and calcium on yields and fruit quality of young 'Valencia' oranges. Proc. Fla. State Hort. Soc. 84:4-10.

Anderson, C.A. and D.V. Calvert. 1965. Comparisonsofcalciticanddolomiticlimestone in citrus groves on six soils. Proc. Fla. State Hort. Soc. 78:15-21

Carlislie, V.W., F. Sodek, III, M.E. Collins, L.C. Hammond, and W.G. Harris. 1989. Characterization data for selected Florida soils. Soil Sci. Res. Rpt. 89-1. Univ. of Florida, U.S. Dept. of Agriculture, and Soil Conservation Sot.

Ferguson, J.A. and J.T. Gilmour. 1981. A hydraulic carbonatechemistrymodeloffloodedricefields. Ark. Water Resources Res. Center Publ. 78.

Ferguson,J.A.,J.T.Gilmour, andC.L. Griffis. 1975. A water management model of predicting carbonate accumulation in rice soils. Ark. Farm Res. 24:5.

Gilmour, J.T. and J.A. Ferguson. 1981. Liming silt loam soils cropped to rice and soybeans. Ark. Farm Res. 30:7.

Gilmour, J.T., K.S. Shirk, J.A. Ferguson, and C.L. Griffis. 1978. A kinetic study of the $\mathrm{CaCO}$ precipitationreaction.Agr.WaterMgmt.1:253262 .

Jones, G.W., E.C. Dehaven, L.F. Clark, J.T. Rauch, J.R. Rasmussen, and C.G. Guillen. 1990.
Groundwaterqualitysamplingresultsfromwells in the southwest Florida water management district:Northern, central, and southern region. Joint Rpt., Southwest Fla. Water Mgmt. District, Brookville, and Fla. Dept. Environ. Regulat.,Tallahasee.

Kidder, G. and E.A. Hanlon. 1985. Neutralizing excessbicarbonatesfromirrigationwater.Notes Soil Sci. Florida Coop. Ext. Serv., Univ. of Florida, Gainesville. 18:10.

Koo, R.C.J., C.A. Anderson, I. Stewart, D.P.H. Tucker,D.V.Calvert,andH.K. Wutscher. 1984. Recommendedfertilizersandnutritional sprays for citrus. Univ. of Florida, Inst. of Food and Agricultural Sciences Bul. 536D.

Marx, D.B., J.T. Gilmour, H.D. Scott, and J.A. Ferguson. 1988. Effects of long-term water management in a humid region on spatial variabilityofsoilchemicalstatus.SoilSci.145: 188 193.

Mehlich, A. 1953. Determination of P, K, Na, Ca, $\mathrm{Mg}$ and $\mathrm{NH}_{4}$. Soil Test Div. Mimeo., North Carolina Dept. of Agriculture, Raleigh.

Mortvedt, J.J., P.M. Giordano, and W.L. Lindsay (eds.).1972.Micronutrients in agriculture. Soil Sci. Soc. Amer., Madison, Wis.

Parsons,L.R.1989.Managementofmicro-irrigation systems for Florida citrus. Fruit Crops Fact Sheet,FC-81. Florida Coop. Ext. Serv., Univ. of Florida, Gainesville. 